\title{
ANALISIS ASPEK HUKUM UMKM DAN UKM DI INDONESIA DALAM KAITANNYA DENGAN PENGEMBANGAN EKONOMI
}

\author{
Alva Ruslina, Bernard Nainggolan, Wiwik Sri Widiarty \\ Universitas Kristen Indonesia (UKI) Jakarta, Indonesia \\ Email: alvaruslina11@gmail.com, bernard.nainggolan@uki.ac.id, \\ wiwik.sriwidiarty@uki.ac.id
}

\begin{abstract}
INFO ARTIKEL ABSTRAK
Diterima

25 Oktober 2021

Direvisi

05 November

2021

Disetujui

15 November

2021

Kata Kunci:

perlindungan

konsumen; peer

to peer lending;

otoritas jasa

keuangan

Pinjaman online yang saat ini banyak diminati oleh masyarakat Indonesia tidak hanya memberikan dampak positif tetapi juga ada resiko yang sudah terjadi setelah melakukan transaksi tersebut. Kemudahan dalam melakukan transaksi pinjaman memberikan peluang bagi pijaman ilegal untuk melakukan aksinya, maraknya kasus pinjaman online yang terjadi di Indonesia menjadi alasan utama permasalahan ancaman yang diterima oleh konsumen akibat pinjaman online ilegal. Tidak hanya ancaman tetapi pelaku juga menyebarkan data pribadi korban merupakan suatu pelanggan undang-undang Transaksi Elektronik dan melanggar aturan yang ditetapkan oleh Otoritas Jasa Keuangan karena tidak ada ijin. Upaya perlindungan hukum harus ditegaskan bagi setiap pihak yang ikut berperan dalam finansial teknologi peer to peer lending. Perlindungan hukum yang diterapkan harus juga melibatkan konsumen serta setiap platform untuk mengikuti regulasi yang ditetapkan. Regulasi tersebut harus memberikan keadilan bukan hanya kepada satu pihak tetapi seluruh pihak hingga pihak ketiga. Sebagai lembaga Otoritas Jasa Keuangan, atau yang disingkat OJK memiliki peranan dalam memberikan sosialisasi terkait dengan regulasi yang ada. Pendekatan serta sosialisasi harus diusahakan secara terus-menerus agar dapat memberikan keadilan bagi setiap pihak. Upaya yang dilakukan Otoritas Jasa Keuangan juga melibatkan peran asosiasi fintech pendanaan bersama Indonesia dengan menampung aspirasi masyarakat dalam memberikan rasa aman.
\end{abstract}

\section{ABSTRACT}

Online loans, which are currently in great demand by the Indonesian people, not only provide positive benefits but also have risks that have occurred after making the transaction. The ease of conducting loan transactions provides an opportunity for illegal lenders to take action, the rise of online loan cases that occur in Indonesia is the main reason for the problem of threats received by consumers due to illegal online loans. Not only
How to cite:

E-ISSN:

Published by:
Ruslina, A., Bernard Nainggolan, \& Wiwik Sri Widiarty. (2021) Analisis Aspek Hukum UMKM dan UKM Di Indonesia dalam Kaitannya dengan Pengembangan Ekonomi. Jurnal Syntax Admiration 2(11). https://doi.org/10.46799/jsa.v2i11.336 2722-5356

Ridwan Institute 


\begin{tabular}{|c|c|}
\hline & $\begin{array}{l}\text { threats, but the perpetrators also spread the victim's personal data } \\
\text { which is a violation of the Electronic Transactions law and } \\
\text { violates the rules set by the Financial Services Authority because } \\
\text { there is no permission. Legal protection efforts must be } \\
\text { emphasized for every party who plays a role in peer to peer } \\
\text { lending technology finance. The legal protection applied must } \\
\text { also involve consumers and every platform to follow the } \\
\text { regulations set. The regulation must provide justice not only to } \\
\text { one party but to all parties to third parties. As an institution of the } \\
\text { Financial Services Authority, or abbreviated as OJK, it has a role }\end{array}$ \\
\hline $\begin{array}{l}\text { Keywords: } \\
\text { consumer } \\
\text { protection; peer } \\
\text { to peer lending; } \\
\text { financial services } \\
\text { authority }\end{array}$ & $\begin{array}{l}\text { in providing socialization related to existing regulations. } \\
\text { Approaches and socialization must be pursued continuously in } \\
\text { order to provide justice for each party. Efforts made by the } \\
\text { Financial Services Authority also involve the role of fintech } \\
\text { associations with joint funding of Indonesia by accommodating } \\
\text { the aspirations of the community in providing a sense of security. }\end{array}$ \\
\hline
\end{tabular}

\section{Pendahuluan}

Salah satu kriteria suatu negara yang dikategorikan maju atau tidak adalah perkembangan ilmu pengetahuan dan teknologinya. Perkembangan teknologi juga merupakan indikator dari jenis dan pola produksi. Perkembangan dan pemilihan teknologi akan mempengaruhi bisnis. Terkait dengan pertumbuhan ekonomi yang disebabkan oleh banyak teknologi baru telah ditemukan. Di antara wäktu penemuan inovasi-inovasi utama juga berdampak pada ekonomi yang mengalami stagnasi. karena negara lebih percaya pada sesuatu yang datang dari luar dari pada karya anak bangsa. Beberapa pakar ekonomi percaya bahwa stagnasi ekonomi: sekarang ini akan bekelanjutan terus hingga muncul inovasi yang disebut dengan platform, perpidahan sebuah produk yang berubah menjadi platform, kehidupan usaha juga terus mengalami perubahan. Aktivitas yang dilakukan juga tidak saja melalui individu tetapi juga platform dengan platform lainnya. Inilah peradaban informasi yang segala sesuatunya berawal dari data yang menjadi informasi dan memberi pengetahuan.

Lacy, Hagenmueller, dan Ising mencatat, dalam platform, siapa pun kompetitor pada masa lalu bisa berubah menjadi mitra kerja yang dekat. Sebaliknya, yang dulu menjadi mitra bisnis menjadi pesaing yang mematikan. Kehidupan tak lagi sekedar konsumsi, melainkan partisipasi yang meningkat. Platform itulah yang menjadikan pelaku-pelaku ekonomi dan negara-negara tertentu mendominasi dunia pada abad 21 ini. Tercatat tiga dari lima perusahaan dengan kapitalisasi terbesar dunia pada 2014 (Apple, Google, dan Microsoft) berbentuk platform (Budhijanto, 2017). Namun, pada 2017, sudah puluhan perusahaan yang berbentuk platform: Apple, Google, Microsoft, Amazon, IBM, Samsung, Intel, Cisco, SAP, Nike, Facebook, dan sebagainya. Demikian juga kampus-kampus kelas dunia yang menghimpun pengetahuan terdepan (Harvard, MIT, Stanford, Chicago, Yale, Cambridge) dan startup-startup yang berhasil menggusur incumbent dan mendominasi ekonomi dunia (Alibaba, Amazon, Ebay, Facebook, 
YouTube, Airbnb, Tencent, Baidu, Softbank). Oleh karena itu sebagai salah satu aktor yang bersaing di dunia, Indonesia juga perlu membangun platform atau setidak-tidaknya mentransformasi sejumlah perusahaan incumbent menjadi platform. Badan Usaha Milik Negara (BUMN) bisa memiliki lima hingga sepuluh platform, grup-grup besar perusahaan swasta, atau bahkan badan-badan pemerintah seperti Astra, Sinarmas, RGE, Lippo Group, Austindo, Djarum Group, Bekraf, dan sejumlah perusahaan nasional lainnya juga bisa menjadi platform. Sebagian startup lokal seperti GO-JEK, Bukalapak, dan Kitabisa.com sudah berbentuk platform. Demikian juga transaksi bisnis terselubung seperti obat-obatan terlarang, online dating, online game (dan olahraga elektronik), perabotan perawatan bayi, dan jasa-jasa tertentu, yang sudah berpindah ke dunia platform dan memengaruhi kehidupan secara luas. Kita perlu menghadapi serangan ekonomi para platform global dengan platform, bukan dengan produk. Demikian juga dengan serangan-serangan psikologis atau politis termasuk dengan pengembangkan technology financial (Kasali, 2018).

Fintech merupakan financial technology atau teknologi finansial. Menurut The National Digital Research Centre (NDRC), di Dublin, Irlandia, mendefinisikan fintech sebagai "innovation in financial services" atau "inovasi dalam layanan keuangan fintech" yang merupakan suatu inovasi pada sektor finansial yang mendapat sentuhan teknologi modern (Iman, 2016). Transaksi keuangan melalui fintech ini meliputi pembayaran, investasi, peminjaman uang, transfer, rencana keuangan dan pembanding produk keuangan. Beberapa perusahaan fintech yang telah ada di Indonesia saat ini, misalnya CekAja, Uang Teman, Pinjam, Cek Premi, Bareksa, Kejora, Doku, Veritrans, Kartuku. Terdapat penambahan 10 (sepuluh) penyelenggara fintech lending berizin pada tahun 2021 yaitu: PT Cicil Solusi Mitra Teknologi, PT Inovasi Terdepan Nusantara, PT Semangat Gotong Royong, PT Kreditku Teknologi Indonesia, PT Pinduit Teknologi Indonesia, PT Modal Rakyat Indonesia, PT Anugerah Digital Indonesia, PT Idana Solusi Sejahtera, PT Trust Teknologi Finansial, dan PT Harapan Fintech Indonesia. Sehingga jumlah perusahaan yang berizin menjadi 56 (lima puluh enam) penyelenggara. Selain itu terdapat penambahan aplikasi milik PT Uangme Fintek Indonesia pada sistem operasi iOS di Apple Appstore yang bernama (UangMe, App Pinjaman Cepat \& Pendanaan Aman). Financial technology memberikan manfaat bagi pertumbuhan industri elektronik (E-commerce) di Indonesia. mendorong tumbuhnya usaha kecil menengah dan lahirnya wirausaha baru, mendukung para pemeran usaha kreatif untuk memperluas distribusi pasar dan mendorong perkembang an pasar, terutama yang masih belum mendapatkan layanan keuangan dan perbankan konvensional. Fintech dianggap lebih fleksibel dibandingkan dengan penyedia layanan pinjaman uang lain nya, seperti bisnis keuangan konvensional atau bank tradisional yang di mana masih terbatasnya peraturan yang mengatur industri layanan keuangan ini. Terlihat pada saat proses pengajuan peminjaman pada jasa keuangan konvensional, konsumen harus melengkapi beberapa proses administrasi. Berbeda dengan bisnis Fintech, yang lebih mudah dalam proses mengajukan pinjaman yang hanya mengunggah dokumen yang dibutuhkan 
melalui internet, dengan menggunakan langkah awal yang mudah maka sangat dibutuhkan aturan yang mengatur layanan tersebut.

Menurut Peraturan Bank Indonesia No.19/12/PBI/2017 tentang penyelenggaraan teknologi finansial menimbang bahwa perkembangan teknologi dan sistem informasi terus melahirkan berbagai inovasi, khususnya yang berkaitan dengan teknologi untuk memenuhi berbagai kebutuhan masyarakat termasuk akses terhadap layanan finansial dan proses transaksi. Perkembangan Fintech pinjaman online di Indonesia, berkembang dengan sangat pesat hingga menimbulkan banyak masalah juga. Salah satunya yang menjadi perhatian utama adalah pinjaman illegal atau tidak berizin yang merugikan masyarakat yang melakukan pinjaman. Oleh karena itu, Otoritas Jasa Keuangan mengeluarkan himbauan kepada masyarakat untuk menggunakan jasa-jasa penyelenggara fintech yang sesuai dengan daftar perusahan yang sudah terdaftar dan mendapat ijin dari pihak Otoritas Jasa Keuangan (OJK). Hal ini mendapat perhatian khusus karena pada tahun 2021, bulan Februari, tercatat keseluruhan total penyaluran dananya mencapai Rp 169.5 Trilius. Jumlah peminjaman semakin naik 889\% dari 4,36 juta nasabah pada 2018 menjadi 43,56 juta nasabah per desember 2020. Kenaikan dan pertubuhan yang pesat inipun tidak berjalan mulus. Terdapat masalah yaitu maraknya pinjaman illegal atau yang tidak mempunyai ijin resmi dari Otoritas Jasa Keuangan. Dalam catatannya Otoritas Jasa Keuangan terdapat 1.026 Fintech Ilegal pada tahun 2020. Padahal hingga saat ini dalam catatannya OJK hanya memberikan ijin kepada 148 pinjaman online yang secara resmi mendaftar. Oleh karena itu pelindungan hukum menjadi suatu dasar utama yang harus diperhatikan konsumen peer to peer lending. Oleh karena itu penulis mengemukakan suatu pokok permasalahan yaitu;

Bagaimana perlindungan hukum bagi konsumen layanan finansial teknologi di Indonesia?

\section{Metode Penelitian}

Berdasarkan permasalahan ini, maka penulis akan menggunakan jenis penelitian hukum normatif yang merupakan suatu proses untuk menemukan aturan hukum, prinsip-prinsip hukum maupun doktrin-doktrin dalam menjawab isu hukum yang dihadapi. Penelitian normatif merupakan suatu penelitian dalam bentuk pendekatan doctrinal yang bersifat yuridis atau normatif. pada dasarnya adalah suatu penelitian yang akan mengkaji aspek-aspek yang digunakan sebagai bahan hukum untuk dapat menyelesaikan masalah yang adalah di dalamnya yang ada dalam hukum positif. Hukum sebagai suatu sistem mempunyai kemampuan untuk hidup, tumbuh dan berkembang di dalam sistemnya sendiri harus diakui menggunakan analisis hukum yang disebut dengan penelitian hukum normatif. Metode penelitian ini juga merupakan suatu pendekatan yang mengacu pada hukum dan peraturan perundang-undangan yang berlaku. Dalam melakukan penelitian penulis menggunakan bahan-bahan hukum dalam menyusun penelitian, bahan-bahan itulah yang bersumber dari sumber data primer, sumber data sekunder dan sumber data tersier. Dimulai dari sumber hukum inilah penulis mengumpulkan data untuk dapat dikelolah (Syamsul, 2012). 
1. Sumber hukum primer adalah bahan hukum yang mengikat terdiri dari:

a. Kitab Undang-Undang Hukum Perdata

b. Undang-Undang Nomor 21 Tahun 2011 Tentang Otoritas Jasa keuangan

c. Undang-undang Informasi Teknologi Elektronik Nomor 11 Tahun 2008

d. Peraturan Otoritas Jasa Keuangan (POJK) Nomor 77/POJK.01/2016 Tentang Layanan Pinjam Meminjam Uang Berbasis Teknologi Informasi (Nomor, 2018a);

e. Surat Edaran Otoritas Jasa Keuangan (SEOJK) Nomor18/SEOJK.02/2017 Tentang Tata Kelola dan Manajemen Risiko Teknologi Informasi pada Layanan Pinjam Meminjam Uang Berbasis Teknologi Informasi (Anoraga, 2000);

f. Peraturan Otoritas Jasa Keuangan Nomor 1/POJK.07/2013 tentang Perlindungan Konsumen Sektor Jasa Keuangan (Nomor, 2018b).

g. Surat Edaran Otoritas Jasa Keuangan Nomor 18/SEJOK.02/2017 tentang Tata Kelola dan Manajemen Risiko Teknologi Informasi Pada Layanan Pinjam Meminjam Uang Berbasis Teknologi Informasi (Candra, 2019).

2. Sumber Bahan Hukum Sekunder

Sumber Hukum Sekunder adalah bahan hukum yang menjelaskan secara umum mengenai bahan hukum primer, hal ini bisa berupa: Buku-buku ilmu hukum.

3. Sumber bahan Hukum Tersier

Yaitu bahan hukum yang mendukung bahan hukum primer dan bahan hukum sekunder. Maka, penulis menggunakan kamus, artikel, atau hal-hal yang mendukung penelitian ini.

4. Tahap Pengumpulan Data

Penelitian ilmu hukum pada dasarnya bukanlah untuk melakukan verifikasi atau menguji hipotesis. Penelitian ilmu hukum Menurut Peter, M, Marzuki dilakukan untuk mencari pemecahan atas isu hukum yang timbul. Dalam penelitian ini penulis menggunakan penelitian hukum normatif yaitu merupakan penelitian hukum kepustakaan. Penelitian hukum kepustakaan mengharuskan penulis untuk melakukan analisis secara deskritif dalam mencari bahan pustaka, seorang peneliti perlu untuk mengetahui seluk-beluk perpustakaan sebagai tempat terhimpunnya data sekunder dalam rangka membantu peneliti untuk menghemat waktu, tenaga dan biaya (Rahardjo, 2006).

Bahan pustaka yang juga disebut sebagai data sekunder terutama dapat diperoleh dari perpustakaan. Banyak orang menganggap perpustakaan hanyalah sebagai suatu tempat terkumpulnya buku-buku atau gudang buku. Pendapat demikian tidaklah benar, oleh karena yang benar adalah perpustakaan merupakan gudang ilmu pengetahuan, sebab perpustakaan merupakan tempat terhimpunnya ilmu pengetahuan yang diperoleh manusia dari masa ke masa. Suatu perpustakan secara sederhana dapat dirumuskan sebagai suatu usaha yang dengan teratur dan sistematis menyelenggarakan pengumpulan perawatan dan pengolahan bahan pustaka untuk disajikan dalam bentuk layanan yang bersifat edukaif.

Suatu penelitian sebelumnya juga memuat tentang; Pengaruh Fintech Terhadap Perkembangan Bisnis UMKM melalui Variabel Intervening Kepuasan Konsumen, 
penelitian yang dikemukakan oleh Agung Akbar Putra Bastian jelas berbeda dengan penelitian ini; Perbedaan terletak pada aspek penelitian penulis ini yang focus pada bidang ekonomi serta pengembangan ekonomi saat finansial teknologi muncul di Indonesia dengan metode penelitian dengan menggunakan alat mengumpulkan data berubah penelitian lapangan serta pandangan pengembangan ekonomi saat kemunculan finansial teknologi berbeda dengan penelitian ini melihat pada sisi perlindungan hukum bagi konsumen finansial teknologi. Dengan menggunakan metode penelitian normativ hukum, serta bahan-bahan yang bersumber pada hukum. Oleh kaena itu, keduanya memiliki persamaaan penelitian pada isu finansial teknologi tetapi tetap saja terdapat perbedaan yang signifikan (Santi et al., 2017).

\section{Hasil dan Pembahasan}

Pada suatu perjanjian terdapat beberapa pihak yang melakukan perjanjian, dalam perjanjian yang melibatkan, salah satu contoh, Ruly Yakub merupakan warga negara Indonesia yang lahir di Jawa Tengah, merupakan seseorang yang melakukan pinjaman dana kepada pemberi pinjaman dalam perjanjian ini adalah Doctor Dana Limited yang merupakan suatu platform di Hongkong, yang diwakili oleh direktur yaitu Zhang Zepeng, transaksi pinjam-meminjam ini dilakukan pada awalnya melalui perjanjian terkait dengan jumlah peminjaman Rp 3,350,000.00 jangka waktu 30 hari dengan besar suku Bunga 0,8 \% untuk setiap hari. Pinjaman juga dilakukan tanpa jaminan. Dalam pinjaman ini jika, penerima pinjaman belum melakukan pembayaran pada tanggal jatuh tempo maka penambahan 5\%, adapun penerima pinjaman dapat memperpanjang tanggal pembayaran 3 hari kedepan jika belum dapat membayar namun, tidak boleh diperpanjang lagi. Selanjutnya bagi pemberi pinjaman dan peminjam tidak diperkenankan melanggar peraturan yang ditetap oleh Otoritas Jasa Keuangan Nomor 77; melanggar perjanjian atau komitmen penerima pinjaman dengan pihak pemberi pinjaman dan pihak yang terkait. Jika mengakses suatu platform sebagai pemberi pinjaman seharusnya memiliki hak untuk menerima pelunasan pinjaman tepat pada waktu yang ditentukan. Kewajiban yang dimiliki oleh pemberi pinjaman yaitu menggunakan platform yang sesuai dengan peraturan perundang-undangan yang berlaku di Republik Indonesia. Dalam suatu perjanjian yang resmi juga dijelaskan terkait dengan pinjaman setelah tanggal jatuh tempo penerima pinjaman belum juga melunasi kewajiban dalam mengembalikan pinjaman kepada pemberi pinjaman maka pinjaman mengizinkan penyelenggara untuk mengeluarkan surat peringatan kepada penerima pinjaman sebagai bentuk peringatan untuk membayaran kewajiban. Dalam suatu perjanjian pinjaman juga terdapat cedera janji yang artinya hak, kewajiban, batasbatas aktivitas seluruh pihak yang terkait sudah di atur dalam isi perjanjian. Dalam menyelesaian sengketa juga diatur dalam hukum. Proses pinjaman online seharusnya memuat berbagai ketentuan-ketentuan yang mengatur pihak-pihak yang terlibat dalam suatu perjanjian. Agar seluruh pihak dapat menjalankan hak-hak serta kewajibannya sesuai dengan peraturan yang ada dan disepakati bersama. Jika tidak maka, yang terjadi adalah kerugian akibat dari pinjaman online yang tidak terdaftar, maka perlindungan 
hukum sangat penting untuk diberikan bagi konsumen (Shidarta, 2018).

Maraknya kasus pinjaman online di Indonesia maka nasabah harus waspada dan paham ciri-ciri pinjaman online yang ilegal. Tingginya minat pasar untuk mengambil pinjaman melalui perusahaan teknologi finansial (fintech) membuat pertumbuhan pinjaman online semakin massif, maka harus ada perlindungan hukum bagi konsumen pinjaman online. Pinjaman ilegal sangat agresif dalam melakukan penawaran melalui pesan singkat atau e-mail dan lainnya. Berbeda dengan pinjaman online yang terdaftar di Otoritas Jasa Keuangan dilarang mengirimkan promosi selain kepada pengguna. Kedua, pinjaman dari pinjaman online ilegal biasanya singkat, misalkan dalam 7 hari atau 14 hari. Biasanya, setelah melewati batas pinjaman, pinjaman online ilegal akan mengirimkan dana secara otomatis ke rekening anda. Begitu sudaah lunas dana masuk lagi, lalu utang lain. Hal-hal ini harus di tindak dengan tegas dan hak dari konsumen juga harus dilindungi (Tumanggor, 2012).

Pinjaman online illegal tidak memiliki aturan pasti tentang penetapan bunga kredit. Pinjol ilegal juga tidak transparan soal bunga kredit, biasanya bunga muncul setelah dana diterima dan melebih batasan yang telah ditentukan oleh Asosiasi Fintech Pendanaan Bersama Indonesia dan Otoritas Jasa Keuagan. Pinjaman online legal hanya diperbolehkan untuk memberikan bunga sebesar 0,8 persen per hari dan menghitung dalam 90 hari. Artinya tidak sesuai dengan aturan dasar yang dikeluarkan oleh Otoritas Jasa Keuangan. Umumnya pinjol ilegal hanya membutuhkan Kartu Tanda Penduduk dan permintan dana langsung diproses (Widiarty, 2016). Pinjaman online ilegal tidak akan melakukan konfirmasi ke pihak yang bersangkutan pada seharusnya ada konfirmasi ke pihak yang bersangkutan. Di lain pihak, dalam transaksi online, setiap konsumen bertindak atas namanya sendiri tanpa berhubungan dengan konsumen lain masing-masing beroperasi secara terpisah dari yang lain karena konsumen tidak mengetahui adanya konsumen lain atau tidak dapat berkomunikasi dengan konsumen lain tersebut. Sangat berbeda dengan transaksi 'dunia nyata', pada transaksi Net kecil kemungkinan membentuk kelompok pendukung konsumen yang sesuai dengan wewenang dan legitimasi dengan menggunakan tekanan pada bisnis dan juga pemerintah untuk melibatkan diri dan melaksanakan bermacam-macam bentuk perlindungan yang mengacu pada bentuk terdahulu secara singkat (Valerine, 2015).

Kelompok pendukung konsumen menganjurkan perlindungan konsumen yang secara khusus dibentuk berdasarkan, dan dalam batas, undang-undang pemerintahan Iokal, baik undang-undang tersebut mengijinkan operasional mereka dengan jelas atau tidak, atau berdasarkan hak konstitusional asosiasi yang bebas (Miru, 2004). Kenaikan pertumbuhan ekonomi di Indonesia berdasarkan data dari Badan Pusat Statistik (BPS) pertumbuhan ekonomi Indonesia pada kuartal 2020 sebesar 2,97\% year-on-year (yoy). Pertumbuhan ekonomi triwulan 2020 ini, lebih rendah dari kuartal I-2019 yang 5,07\% . Penurunan pertumbuhan ekonomi ini, disebabkan oleh turunnya sejumlah ekspor Indonesia, salah satunya ke China dan Amerika Serikat, dua negara tujuan ekspor terbesar Indonesia. Hal ini merupakan dampak dari pandemi wabah virus corona yang membuat sejumlah negara melakukan lockdown sehingga perdagangan ekspor impor 
terdampak luas. Penurunan pertumbuhan ekonomi ini juga berdampak kepada jumlah populasi, tingkat inflasi dan biaya hidup yang semakin tinggi di Indonesia. Dimana hal ini juga menyebabkan maraknya Pinjaman Online untuk memenuhi kebutuhan sosial. Perkembangan teknologi yang tidak terbatas di era digital sekarang ini, semakin lengkap dengan hadirnya salah satu bentuk penerapan teknologi informasi di bidang keuangan, yaitu aplikasi Pinjaman Online. Pinjaman Online merupakan fasilitas pinjaman uang oleh penyedia jasa keuangan yang terintegrasi dengan teknologi informasi, mulai dari proses pengajuan, persetujuan hingga pencairan dana dilakukan secara online atau melalui konfirmasi SMS dan/atau telepon.

Banyak orang berpikir bahwa Pinjaman Online ini adalah solusi yang mudah dan cepat untuk mendapatkan uang. Namun ternyata dibalik kenyamanan ini, tentu ada konsekuensi dan risiko yang akan diterima oleh pelanggan jika mereka melanggar kewajiban mereka. Perkembangan industri fintech ini juga lekat dengan stigma negatif dari masyakarat khususnya dalam cara penagihan. Permasalahan Pinjaman Online atau Financial Technology Peer To Peer Lending (Fintech P2P) kian hari terus menjadi sorotan publik. Berbagai kasus pelanggaran Perusahaan Fintech mulai bermunculan di media massa. Bentuk pelanggaran oleh Perusahaan Fintech ini juga beragam jenisnya. Mulai dari penagihan intimidatif (Pasal 368 KUHP dan Pasal 29 jo 45 UU ITE), penyebaran data pribadi (Pasal 32 jo Pasal 48 UU ITE), penipuan (Pasal 378 KUHP) hingga pelecehan seksual melalui media elektronik (Pasal 27 Ayat 1 jo 45 Ayat 1 UU ITE) yang diduga terjadi dalam persoalan ini. Ragam dugaan pelanggaran tersebut salah satunya bersumber dari hasil laporan pengaduan masyarakat yang diterima oleh berbagai Lembaga Bantuan Hukum (LBH) sejak tahun lalu. Terakhir, permasalahan fintech ini bahkan merenggut nyawa nasabah yang memilih bunuh diri akibat depresi karena penagihan pinjaman tersebut. Sayangnya, penyelesaian hukum permasalahan ini masih minim sehingga kasus-kasus serupa terus bermunculan. Sebagaimana disebutkan dalam Pasal 7 POJK 77/2016, Penyelenggara wajib mengajukan pendaftaran dan perizinan kepada Otoritas Jasa Keuangan. Berdasarkan kajian hukum perdata pada teknologi finansial bahwa perbuatan hukum yang timbul antara debitur dengan kreditur didasari dengan adanya perjanjian.

Selain itu dalam permasalahan Pinjaman Online, banyak orang telah mengeluhkan mengenai penyebarluasan data pribadi yang dilakukan oleh pihak penyelenggara Pinjaman Online tanpa pemberitahuan dan tanpa izin dari pemiliknya. Hasil studi menunjukan bahwa perlindungan hukum dan sanksi bagi pelanggaran data pribadi telah diatur dalam Pasal 32 jo Pasal 48 Undang-Undang Nomor 11 Tahun 2008 tentang Informasi dan Transaksi Elektronik, namun secara khusus mengenai perlindungan hukum dan sanksi pelanggaran data pribadi dalam layanan Pinjaman Online telah tercantum dalam Peraturan Otoritas Jasa Keuangan Nomor 77/POJK.01/2016 tentang Layanan Pinjam Meminjam Uang Berbasis Teknologi Informasi, sebagaimana ditegaskan dalam Pasal 26 bahwa pihak penyelenggara bertanggung jawab menjaga kerahasiaan, keutuhan dan ketersediaan data pribadi pengguna serta dalam pemanfaatannya harus memperoleh persetujuan dari pemilik data pribadi kecuali 
ditentukan lain oleh ketentuan peraturan perundang-undangan. Sanksi terhadap pelanggaran data pribadi mengacu pada Pasal 47 ayat (1), yaitu sanksi administratif berupa peringatan tertulis, denda, kewajiban untuk membayar sejumlah uang tertentu, pembatasan kegiatan usaha dan pencabutan izin.

Masyarakat awam hukum tentunya merasa khawatir menghadapi permasalahan hukum tersebut. Di sisi lain, perlindungan hukum bagi nasabah Pinjaman Online merupakan aspek serius untuk ditangani oleh pihak berwajib. Perlindungan Pengguna Layanan berdasarkan Pasal 29 POJK 77/2016, Penyelenggara wajib menerapkan prinsip dasar dari perlindungan Pengguna yaitu, transparansi, perlakuan yang adil, keandalan, kerahasiaan dan keamanan data, serta penyelesaian sengketa Pengguna secara sederhana, cepat dan biaya terjangkau. Bagi Penyelenggara atau Perusahaan Finansial teknologi dapat dikenakan sanksi apabila melanggar ketentuan Pasal 43 dan Pasal 47 POJK 77/2016, yang berbunyi sebagai berikut:

Pasal 43:

a. melakukan kegiatan usaha selain kegiatan usaha Penyelenggara yang diatur dalam Peraturan Otoritas Jasa Keuangan ini;

b. bertindak sebagai Pemberi Pinjaman atau Penerima Pinjaman;

c. memberikan jaminan dalam segala bentuknya atas pemenuhan kewajiban pihak lain;

d. menerbitkan surat utang;

e. memberikan rekomendasi kepada Pengguna;

f. mempublikasikan informasi yang fiktif dan/atau menyesatkan;

g. melakukan penawaran layanan kepada Pengguna dan/atau masyarakat melalui sarana komunikasi pribadi tanpa persetujuan Pengguna; dan

h. mengenakan biaya apapun kepada Pengguna atas pengajuan pengaduan.

Pasal 47: Atas pelanggaran kewajiban dan larangan dalam peraturan OJK ini, OJK berwenang mengenakan sanksi administratif terhadap Penyelenggara berupa:

1. peringatan tertulis;

2. denda, yaitu kewajiban untuk membayar sejumlah uang tertentu;

3. pembatasan kegiatan usaha; dan

4. pencabutan izin.

Terkait hal tersebut, permasalahan ini termasuk kategori perjanjian utang-piutang sehingga bukan ranah pidana melainkan perdata. Untuk itu perlindungan hukum bagi nasabah Pinjaman Online masih lemah dan konsumen masih banyak dirugikan, karena sanksi terhadap penyelenggara atau Perusahaan Fintech masih sebatas sanksi administratif. Terhadap nasabah yang ingin melakukan pengaduan maka dapat disampaikan kepada lembaga terkait kerugian sebagai konsumen, seperti Yayasan Lembaga Konsumen Indonesia (Pasal tersebut di atas tidak memiliki penjelasan perinci tentang perlindungan konsumen. Akan tetapi jika dikaitkan dengan penjelasan Pasal 23 ayat (3) UU-ITE maka norma "menyesatkan" dalam perlindungan konsumen diantaranya dilakukan jika melanggar nama domain internet Kasus nama domain Internet di Indonesia yang fenomenal adalah kasus nama domain Mustika Ratu pada tahun 2000. Terdapat dua isu fundamental yang sering luput dari analisis dan penjelasan 
di kalangan yuris tentang hukum siber, yaitu pertama: wilayah (space) public atau private dan peserta tindak pidana. Kedua isu tersebut di atas perlu untuk dipahami karena memiliki implikasi siginifikan khususnya dalam lingkup hukum pidana untuk menentukan locus (tempat berlakuya hukum pidana) dan tempus (waktu terjadinya peristiwa pidana). Dengan paradigma siber sebagai sebuah wilayah publik dan privat dalam siber sebenarnya tidak terlalu sulit. Misalnya ketika seseorang mengirimkan sebuah surat elektronik (email) ke temannya, maka isi surat itu sifatnya sudah tentu bersifat pribadi. Tetapi jika ada sebuah pernyataan atau pendapat yang tuliskan dalam media sosial yang dapat diakses oleh umum (publik), maka sifat dari pernyataan tersebut pastilah publik. Walaupun tetap terbuka untuk diperdebatkan jika format forum di media sosial tempat menyatakan pendapat tersebut diatur menjadi privat apakah dapat bisa dikatakan sebagai wilayah publik. Karena secara umum media sosial di gunakan sebagai tempat publik untuk dapat diakses oleh khalayak ramai, maka seharusnya dapat dikatakan publik.

Jika melihat pada, Aturan yang disusun dalam upaya memberikan sangsi bagi pelaku fintech yang illegal. Pasal 31 Undang-undang Nomor 21 Tahun 2011 tentang Otoritas Jasa Keuangan. Perlindungan Konsumen ini meliputi semua perilaku Pelaku Usaha Jasa Keuangan. regulator menegaskan fintech Pear to pear lending yang telah terdaftar wajib mematuhi aturan dari Peraturan Otoritas Jasa Keuangan (POJK) Nomor 77 tahun 2016 tentang Layanan Pinjam Meminjam Uang Berbasis Teknologi Informasi dan POJK Nomor 18 tahun 2018 tentang Perlindungan Konsumen Sektor Jasa Keuangan. Untuk selanjutnya Otoritas Jasa Keuangan akan menindak apabila memang terbukti fintech-fintech yang terdaftar ini melakukan tindakan pelanggaran terhadap aturan perundang-undangan. Jadi tidak ada perbedaan perlakuan. Maraknya perusahaan financial technology (fintech) peer to peer $(P 2 P)$ lending ilegal menimbulkan kekhawatiran tersendiri bagi masyarakat. Oleh karena itu, Otoritas Jasa Keuangan (OJK) mengimbau kepada masyarakat untuk ikut aktif dalam mengawasi pergerakan fintech ilegal.

Penemuan fintech yang beroperasi secara ilegal, fintech tersebut dapat dikenai sanksi pidana. Sebab, pada dasarnya pengawasan fintech bukan menjadi wewenang langsung Otoritas Jasa Keuangan. Fintech $P 2 P$ lending ilegal tidak di bawah pengawasan Otoritas Jasa Keuangan sehingga, sanksi yang diberikan ada sanksi pidana dalam hal terdapat tindak pidana. Sebagai informasi, Otoritas Jasa Keuangan secara berkala menginformasikan daftar fintech ilegal yang tidak terdaftar di Otoritas Jasa Keuangan melalui laman resmi dari Otoritas Jasa Keuangan. Selain itu, juga telah menggandeng Kementerian Komunikasi dan Informatika (Kominfo) untuk bersamasama memonitoring fintech-fintech yang beroperasi di Tanah Air. Hal ini menjadi penting sehingga, peran masyarakat amat dibutuhkan sehingga Otoritas Jasa Keuangan atau disingkat OJK dapat melakukan investigasi dengan maksimal atas fintech yang bermasalah. Setidaknya, masyarakat harus dapat memastikan bahwa fintech yang dituju telah teregistrasi di OJK. Supaya tidak ada masalah yang terulang karena setiap warga negara berhak atas perlindungan hukum yang wajib diberikan oleh negara. Salah satu 
perlindungan yang wajib diberikan oleh negara adalah perlindungan konsumen.

Hal ini dilakukan agar masyarakat tidak mengkonsumsi atau menggunakan produk barang dan atau jasa yang dapat membahayakan keselamatan, kesehatan dan sebagainya, sehingga masyarakat merasa aman serta memperoleh kepuasan. Sekali seorang konsumen mengonsumsi atau membeli suatu produk, maka konsumen terscbut bisa saja menderita atau terluka akibat cacat produk, termasuk luka, rusak pada produk tersebut atau pada barang lain dan kerugian secara ekonomi. Dalam Undang-undang RI Nomor 8 Tahun 1999 tentang Perlindungan Konsumen (UUPK) dinyatakan secara tegas klausul tentang tanggung jawab yang harus diberikan oleh pelaku usaha kepada konsumen. Dalam Pasal 19 ayat (1) disebutkan bahwa "Pelaku usaha bertanggung jawab memberikan ganti rugi atas kerusakan, pencemaran, dan/atau kerugian konsumen akibat mengkonsumsi barang dan/atau jasa yang dihasilkan atau diperdagangkan." Mengacu kepada teori sistem hukum yang dikembangkan Friedman tentang tanggung jawab, terdapat tiga substansi hukum tanggung jawab produk yang menjadi dasar tuntutan ganti kerugian konsumen. Ketiga dasar tuntutan tersebut adalah tuntutan karena kelalaian (negligence), tuntutan karena wanprestasi atau ingkar janji (breach of warranty). Hal ini dilakukan karena secara alamiah kedudukan atau posisi konsumen tidak sama dengan produsen sebagai pelaku usaha. Hukum perlindungan konsumen timbul akibat posisi konsumen yang sangat lemah, sehingga perlu mendapat perlindungan hukum. Salah satu sifat sekaligus tujuan hukum itu adalah memberikan perlindungan dan pengayoman kepada masyarakat. Hukum perlindungan konsumen merupakan bagian dari hukum konsumen yang memuat asas-asas dan kaidah-kaidah dan bersifat mengatur dan juga mengandung sifat melindungi kepentingan konsumen. Hukum perlindungan konsumen tidak dapat berdiri sendiri sebagai suatu sistem tetapi harus terintegrasi juga kedalam suatu sistem perekonomian, yang didalamnya terlibat juga para pelaku usaha.

\section{Kesimpulan}

Perlindungan Hukum bagi konsumen layanan finansial teknologi terdapat dalam peraturan Otoritas Jasa Keuangan, Nomor 1/POJK.07/2013 Tentang Perlindungan Konsumen Sektor Jasa Keuangan dalam Pasal 1 dan 2 menjelaskan beberapa prinsip yang mendasar bagi perlindungan konsumen. Ketentuan ini, yang menjadi perhatian bagi pihak-pihak yang terlibat dalam aktivitas pinjaman online, jika ditemukan ketidaksesuaian dalam kenyataannya maka, sangsi harus ditegakan dan diberikan kepada pihak yang menciptakan kerugian bagi konsumen. oleh karena itu, perlindungan hukum terhadap konsumen finansial teknologi di Indonesia belum sepenuhnya memenuhi kepentingan masyarakat atau pengguna layanan, dalam hal ini konsumen layanan pinjaman online. Selanjutnya diharapkan pemerintah melalui lembaga pengawas yang berwewenang memberikan kebijakan yang tegas untuk memberikan perlindungan hukum bagi pengguna layanan pinjaman online Perlindungan Hukum terhadap korban pinjaman online yang tidak resmi, mendapat perhatian khusus dari Otoritas Jasa Keuangan dan Asosiasi Financial Teknologi pendanaan bersama 
Analisis Aspek Hukum UMKM dan UKM Di Indonesia dalam Kaitannya dengan Pengembangan Ekonomi

Indonesia. Berdasarkan laporan kejadian yang sudah dilaporkan. Sebagai lembaga pengawas kebijakan Otoritas Jasa Keuangan didasarkan pada Peraturan No 77. POJK.01/2016 memberikan perlindungan hukum. 


\section{BIBLIOGRAFI}

Anoraga, P. (2000). Manajemen bisnis. Google Scholar

Budhijanto, D. (2017). Revolusi Cyber Law Indonesia Pembaruan dan Revisi UU ITE 2016. Bandung: PT Refika Aditama. Google Scholar

Candra, P. (2019). Penerapan Peraturan Otoritas Jasa Keuangan Nomor 77/Pojk. 01/2016 Tentang Layanan Pinjaman Meminjam Berbasis Teknologi Informasi Terhadap Perjanjian Penyediaan Layanan Peer To Peer $(P 2 p)$ Lending (Studi Kasus: Cicil. Co. Id Dengan" No"). Universitas Gadjah Mada. Google Scholar

Iman, N. (2016). Financial Technology dan Lembaga Keuangan. Gathering Mitra Linkage Bank Syariah Mandiri Yogyakarta. Google Scholar

Kasali, R. (2018). The Great Shifting Series on Disruption. Google Scholar

Miru, A. (2004). Hukum perlindungan konsumen. Google Scholar

Nomor, P. O. J. K. (2018a). 13/POJK. 02/2018 tentang Inovasi Keuangan Digital di Sektor Jasa Keuangan. Lembaran Negara Tahun. Google Scholar

Nomor, P. O. J. K. (2018b). 18/POJK. 07/2018 tentang Layanan Pengaduan Konsumen di Sektor Jasa Keuangan. Lembaran Negara Republik Indonesia Tahun. Google Scholar

Rahardjo, S. (2006). Ilmu Hukum. PT Citra Aditya Bakti. Bandung. Google Scholar

Santi, E., Budiharto, B., \& Saptono, H. (2017). Pengawasan otoritas jasa keuangan terhadap financial technology (peraturan otoritas jasa keuangan nomor 77/pojk. 01/2016). Diponegoro Law Journal, 6(3), 1-20. Google Scholar

Shidarta, A. R. (2018). Aspek Hukum Ekonomi \& Bisnis. Prenada Media. Google Scholar

Syamsul, A. (2012). Buku Ajar Pengantar Hukum Indonesia. Medan: Medan Area University Press. Google Scholar

Tumanggor, M. S. (2012). Pengenalan Otoritas Jasa Keuangan: Pasar Uang, Pasar Modal dan Penanaman modal. F. Media: Jakarta. Google Scholar

Valerine, J. L. K. (2015). Metode Penelitian Hukum (Bagian I). Jakarta: Program Pasca Sarjana Fakultas Hukum Universitas Indonesia. Google Scholar 
Analisis Aspek Hukum UMKM dan UKM Di Indonesia dalam Kaitannya dengan Pengembangan Ekonomi

Widiarty, W. S. (2016). Hukum Perlindungan Konsumen Terhadap Produk Pangan Kadaluwarsa. Komodo Books. Google Scholar

\section{Copyright holder:}

Alva Ruslina, Bernard Nainggolan, Wiwik Sri Widiarty (2021)

First publication right:

Jurnal Syntax Admiration

This article is licensed under:

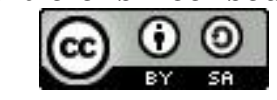

